\title{
Environmental threats we can act upon: How to use the science-policy dialogue
}

\author{
Altermatt, Florian
}

DOI: https://doi.org/10.14512/gaia.30.3.1

Posted at the Zurich Open Repository and Archive, University of Zurich ZORA URL: https://doi.org/10.5167/uzh-212835

Edited Scientific Work

Published Version

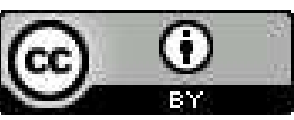

The following work is licensed under a Creative Commons: Attribution 4.0 International (CC BY 4.0) License.

Originally published at:

Altermatt, Florian Environmental threats we can act upon: How to use the science-policy dialogue. Edited by: Altermatt, Florian (2021). München: Oekom Verlag.

DOI: https://doi.org/10.14512/gaia.30.3.1 


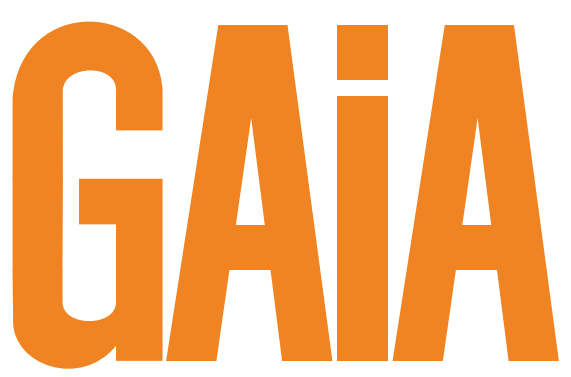

ECOLOGICAL PERSPECTIVES FOR SCIENCE AND SOCIETY

ÖKOLOGISCHE PERSPEKTIVEN FÜR WISSENSCHAFT UND GESELLSCHAFT

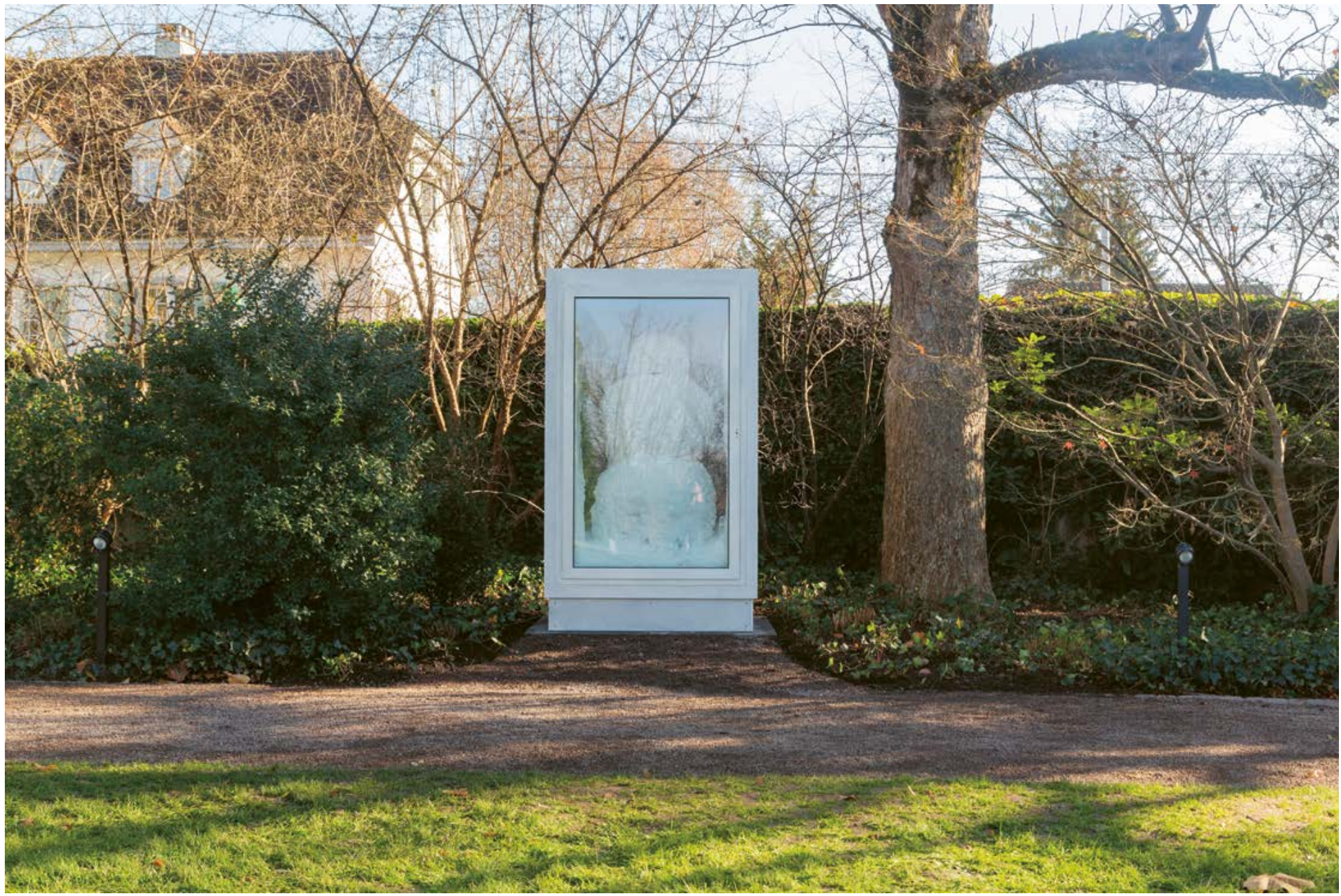

FOCUS: COMMUNICATION AND THE CLIMATE CRISIS

A GLOBAL GREEN NEW DEAL IS FEASIBLE SUSTAINABILITY TRANSITIONS IN RURAL AUSTRIA

GAIA is available online at www.ingentaconnect.com/content/oekom/gaia

www.oekom.de | B 54649 | ISSN print 0940-5550, online 2625-5413 | GAIAEA 30/3, 137-216 (2021)

\section{/IIl oekom}




\title{
Environmental threats we can act upon
}

\author{
How to use the science-policy dialogue
}

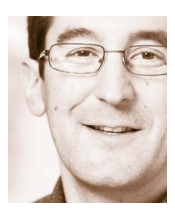

D Prof. Dr. Florian Altermatt Swiss Biodiversity Forum | University of Zurich | Zurich | Switzerland florian.altermatt@ieu.uzh.ch

1 Steffen, W. et al. 2015. Planetary boundaries: Guiding human development on a changing planet. Science 347: 736: 1259855. https://doi.org/10.1126/ science. 1259855

2 Guntern, J. et al. 2020 Übermässige Stickstoff- und Phosphoreinträge schädigen Biodiversität, Wald und Gewässer Swiss Academies Factsheets 15/8. https://doi.org/10.5281/ zenodo.4269637.

3 Guntern, J. et al. 2021.

Pestizide: Auswirkungen auf

Umwelt, Biodiversität und

Ökosystemleistungen.

Swiss Academies Factsheets 16/2.

https://doi.org/10.5281/ zenodo. 4680574 .

4 Gubler, L., S. A. Ismail, I. Seidl.

2020. Biodiversity damaging subsidies in Switzerland.

Swiss Academies Factsheets 15/7.

https://doi.org/10.5281/ zenodo. 3935675 .
_ rom local to global scales, ecosystems are under enormous anthropogenic pressures, and the crossing of planetary boundaries ${ }^{1}$ threatens biodiversity, ecosystem functioning and ultimately human well-being. The need for societal, economic and political action is therefore undisputed.

But how can scientific knowledge be used to inform decision-making? And how and where to start addressing and reversing these threats? The sheer magnitude, interdependency and number of threats seems overwhelming, and may be paralyzing when it comes to taking action. In such situations a twofold strategy is needed both focusing on the major drivers while also being pragmatic on where to start. Ideally, both aspects go hand in hand, which is especially fruitful when underlying incentives are addressed.

The Swiss Biodiversity Forum, part of the Swiss Academy of Sciences (SCNAT), shares a core goal of GAIA, namely providing ecological perspectives and scientific insights to society, with a focus on biodiversity and ecosystem-relevant topics. Doing so, it needs to decide how and when to invest the resources available, and what tools to use. One outlet are factsheets on environmental threats with a high relevancy, such as on negative effects of excessive nitrogen ${ }^{2}$, phosphorus and pesticide ${ }^{3}$ inputs into ecosystems, or on subsidies that directly or indirectly harm biodiversity ${ }^{4}$. To understand how to effectively communicate in a science-policy dialogue with respect to environmental topics, three key aspects have emerged that we deem important for a successful outcome: 1. accuracy and delimitation, 2. timeliness, and 3. extending beyond the traditional "environmental science" perspective.

A scientifically accurate coverage and delimitation of a topic seems obvious, but has proven to be quintessential to withstand possible critique. Timeliness is often underestimated but is also critical to achieve effective arguments: an activity can set an agen$\mathrm{da}$, contribute to opinion making in an ongoing agenda, or take place after a decision is made. With "agenda setting" being the ideal stage, it is often the identification of an ongoing debate or an opportunity that arises and the realization that a contribution to it can make a difference that is most effective, but swift action is always required. Finally, opening new perspectives creates novel leverage. For example, when screening all subsidies in Switzerland on their direct and indirect effects on biodiversity ${ }^{4}$, subsidies harmful to biodiversity were found to be an order of magnitude higher than those designed to benefit biodiversity. Consequently, the key finding was not necessarily to ask for more incentives benefiting biodiversity, but to ask to cut or redirect the harmful ones, the latter simply being the bigger pot to work with.

Eventually, this knowledge needs to be conveyed to key people in governance, economy and politics. Using this approach may make actions to reverse environmental threats more effective. The messages from the above examples were taken up in political and public discussions and contributed to decision-making. A clear score for science and for the scientists involved. 